\title{
Analysis and Prioritization of the Floating Photovoltaic System Potential for Reservoirs in Korea
}

\author{
Sung-Min Kim ${ }^{1}$, Myeongchan $\mathrm{Oh}^{2}$ and Hyeong-Dong Park ${ }^{2,3, *}$ (i) \\ 1 Division of Graduate Education for Sustainability of Foundation Energy, Seoul National University, \\ Seoul 08826, Korea; snuhyrule@hanmail.net \\ 2 Department of Energy Resources Engineering, Seoul National University, Seoul 08826, Korea; \\ amir117@daum.net \\ 3 Research Institute of Energy and Resources, Seoul National University, Seoul 08826, Korea \\ * Correspondence: hpark@snu.ac.kr; Tel.: +82-2-880-8808
}

Received: 31 December 2018; Accepted: 21 January 2019; Published: 24 January 2019

\begin{abstract}
Photovoltaic (PV) energy is one of the most promising renewable energies in the world due to its ubiquity and sustainability. However, installation of solar panels on the ground can cause some problems, especially in countries where there is not enough space for installation. As an alternative, floating PV, with advantages in terms of efficiency and environment, has attracted attention, particularly with regard to installing large-scale floating PV for dam lakes and reservoirs in Korea. In this study, the potentiality of floating PV is evaluated, and the power production is estimated for 3401 reservoirs. To select a suitable reservoir for floating PV installation, we constructed and analyzed the water depth database using OpenAPI. We also used the typical meteorological year (TMY) data and topographical information to predict the irradiance distribution. As a result, the annual power production by all possible reservoirs was estimated to be $2932 \mathrm{GWh}$, and the annual GHG reduction amount was approximately 1,294,450 tons. In particular, Jeollanam-do has many reservoirs and was evaluated as suitable for floating PV installation because of its high solar irradiance. The results can be used to estimate priorities and potentiality as a preliminary analysis for floating PV installation.
\end{abstract}

Keywords: floating photovoltaic system; renewable energy; solar energy; photovoltaic energy; greenhouse gas

\section{Introduction}

To reduce greenhouse gas (GHG) and protect the environment, renewable energy sources are increasingly utilized worldwide. According to Renewable Capacity Statistics [1], the total renewable power capacity for power generation is $2179 \mathrm{GW}$ in 2017, with an $8.3 \%$ increase over the previous year. In particular, the growth rate of photovoltaic (PV) energy is prominent because the price of solar panels is steadily declining, and various stimulus policies are being implemented. PV energy is considered to be one of the most promising energy alternatives due to its ubiquity and sustainability. Particularly in South Korea, PV energy is spreading very quickly after the introduction of the Renewable Portfolio Standards (RPS) program, which requires electricity providers to increase their renewable energy production. PV energy is the renewable energy that accounts for the largest portion in Korea today, except for waste energy and bio-energy. According to the Korea New and Renewable Energy Center (KNREC, Yongin, Korea), renewable energy supply ratio in Korea is about 19.5\%, 61.7\%, $4.3 \%$, and 2.5\% for solar, biomass, hydro, and wind, respectively in 2016. The supply of PV energy in Korea was only 7.6 toe (tonne of oil equivalent) until 2006 but increased to a value of 1092.8 toe in 2016. This is because government policies have been actively implemented, and the public has become actively engaged in 
PV projects to generate profits by selling the produced electricity. However, the excessive installation of PV facilities has caused various problems. In addition to the damage to the landscape caused by the installation of solar panels, the residents of areas where the panels have been installed have been inconvenienced by the reflected light and increase in the ambient temperature. In addition, solar panels that are swept away in the event of landslides or typhoons can cause safety accidents. In recent years, there has been an increase in complaints from local residents, as the solar power generation business has become a means of speculation in the area of PV power generation. These problems can be even more significant in countries such as South Korea, where available land is scarce, so that there is not enough area for the installation of solar panels. Therefore, floating PV systems, which can overcome or alleviate these problems, have attracted considerable attention in these countries.

In addition to being able to utilize the reflected light from the water surface, the floating PV is known to be about $11 \%$ more efficient than the terrestrial solar panel due to the temperature reduction effect in water [2]. Solar panels that cover the water can also reduce evaporation [3] and prevent algae [4] due to shadows by the panels. In other words, the floating PV is advantageous in terms of efficiency and environmental aspects, in addition to the lack of need for land. Because of these advantages, floating PV systems installed on water bodies, such as reservoirs or dam lakes, have increased worldwide and have already been deployed in several countries, including South Korea, Japan, China, and the US [5]. Although most technological growth occurred between 2007 and 2014, the global installed capacity for floating PV has increased significantly since 2015. Floating PV installations in the world were estimated at 94 MW by 2016, of which about $60 \%$ were known to be installed in Japan [6]. In 2017, however, the world's largest floating PV system was installed on the pit lake of a coal mine in China and is known to have capacity of $40 \mathrm{MW}$. The system is composed of 120,000 solar panels, supplying the electricity needs of 15,000 households [7]. Recently, South Korea has been rapidly improving its floating PV technology and increasing installation capacity. The Korea Water Resources Corporation (K-water, Daejeon, Korea) carried out the first demonstration project in South Korea at the Hapcheon reservoir in 2014 with a capacity of $100 \mathrm{~kW}$. In addition, K-water operates South Korea's first commercial system by producing $500 \mathrm{~kW}$ of electricity for approximately 170 households. K-water plans to install 550-MW capacity dam lakes by 2022, and the Korea Rural Community Corporation (KRC, Naju, Korea) is planning 1900 MW of capacity for the reservoirs under management.

Various studies have been conducted to improve and utilize floating PV. There have been many studies on mooring systems to maintain the balance of panels on the water [8,9], and a solar tracking system has been actively studied to improve efficiency $[10,11]$. In recent years, it has become possible to transmit and receive data from a floating PV through the integration of ICT technology [12]. In addition, there have been several studies where Geographical Information System (GIS) techniques have been applied to determine a suitable location for field application and evaluation of the PV potential [13]. Song and Choi [14] evaluated the potential and economic feasibility of a pit lake on the abandoned mine site in Gangwon-do, South Korea, by assessing shadow effects based on GIS techniques and a fish-eye lens camera. Lee and Lee [15] evaluated the applicability of floating PV by region based on the analytic hierarchy process (AHP), considering geographical conditions and weather conditions. Lee et al. [16] evaluated additional parameters to be considered because of the difference between conventional and floating PV systems and evaluated the suitability of the Hapcheon dam area.

There have been many studies regarding individual reservoirs, lakes, and dams, but little research has been conducted on a national scale. Particularly in countries like Korea where large-capacity floating PV systems will be installed in the long term, the PV potential of each available area should be assessed. The purpose of this study is to evaluate the applicability and potential of floating PV for the approximately 3400 reservoirs registered and managed in Korea. 


\section{Study Area and Data}

In this study, we investigated whether floating PV installation is suitable for reservoirs distributed in South Korea. There are 3401 reservoirs managed by the KRC as a database that contains information such as the area of the reservoir, dead water level, full water level, and water storage capacity. The database was downloaded from the Public Data Portal (PDP, data.go.kr). Spatial data such as location and boundary information for each reservoir are also managed and provided to the public. They were downloaded from the National Spatial Data Infrastructure Portal (NSDI, data.nsdi.go.kr). Figure 1a shows reservoir locations, provinces, and some major cities, and Figure $1 \mathrm{~b}$ shows reservoir density across the country. It can be seen that the most reservoirs are concentrated in Jeollanam-do. Using this location data, each reservoir is constructed as point data, and each point object has the name and standard code of the reservoir. Since these standard codes are used in the same way in all the databases, they are used to perform joint work between different data sources. To calculate the area for each reservoir and perform geospatial analysis, information on the boundary of the reservoir was used. Most of the reservoir boundaries and locations are very accurately constructed, except some of the very small reservoirs, when compared with satellite images. To operate floating PV properly, the reservoir needs to have sufficient water depth. Therefore, information on reservoir depth is required for this study, and the PDP provides the level of the reservoir managed by the KRC on a daily basis. This information is provided through OpenAPI, which is a publicly available application programming interface that provides developers with programmatic access to web service. In this study, we constructed a database of the daily reservoir depth over one year in 2017 for all reservoirs through Python coding for OpenAPI. To evaluate the potential of floating PV installed in the reservoir, it is necessary to use the solar irradiance for each site. In this study, we use the typical meteorological year (TMY) data constructed by the Korea Institute of Energy Research (KIER, Daejeon, Korea) to predict the amount of solar irradiance at each site. Global horizontal irradiance (GHI) and direct normal irradiance (DNI) derived from TMY data are used in this study. TMY datasets in 16 cities are created by KIER and distributed by the National Center for Standard Reference Data (NCSRD, Daejeon, Korea). In addition, it is necessary to analyze the shadowing effect to evaluate the power production of floating PV. For this purpose, information about the terrain is needed. In this study, the digital elevation model (DEM) of 90-m resolution, downloaded from the National Geographic Information Institute (NGII, Suwon, Korea), is used. The DEM and TMY observation points for South Korea are shown in Figure 2. 


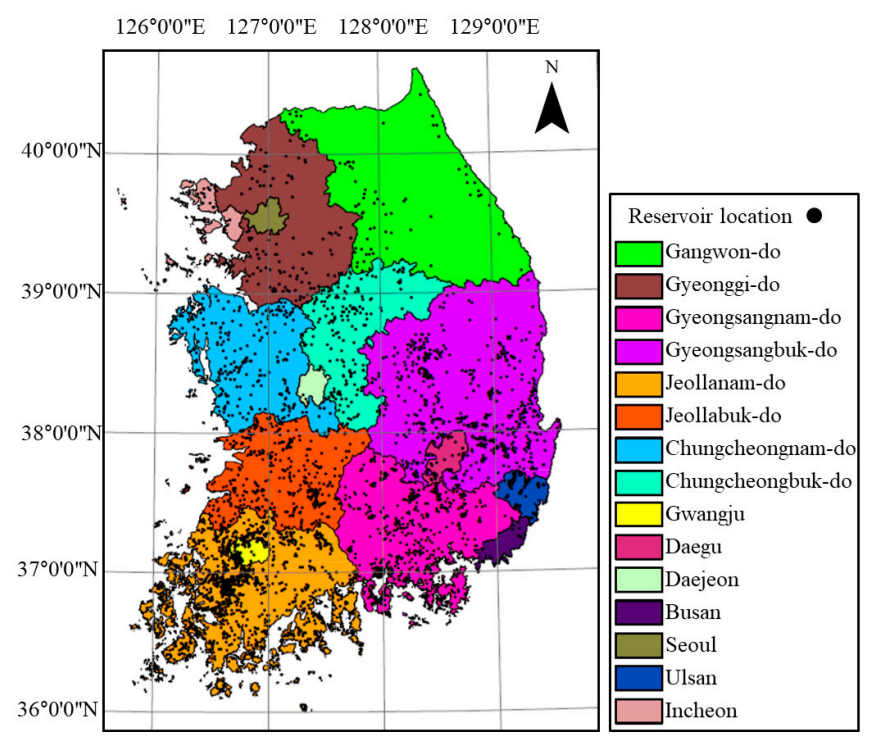

(a)

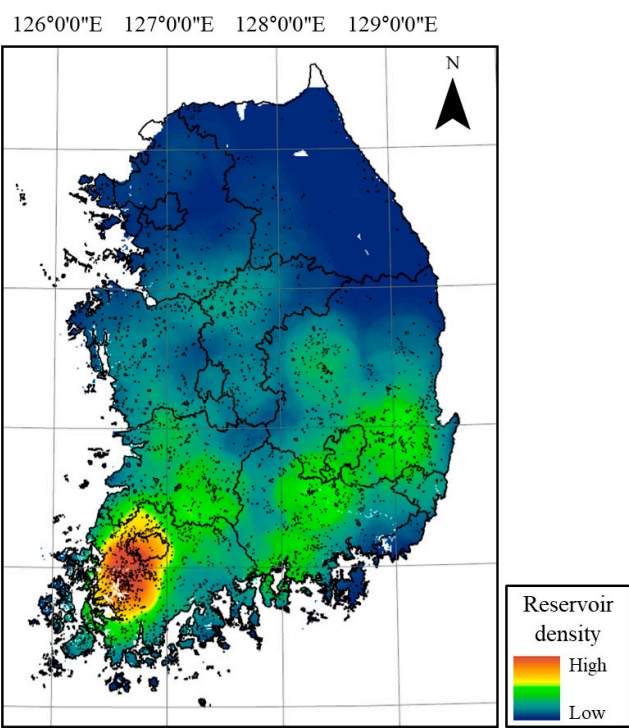

(b)

Figure 1. Reservoirs in Korea: (a) reservoir locations, provinces and some major cities; (b) reservoir density across the country.

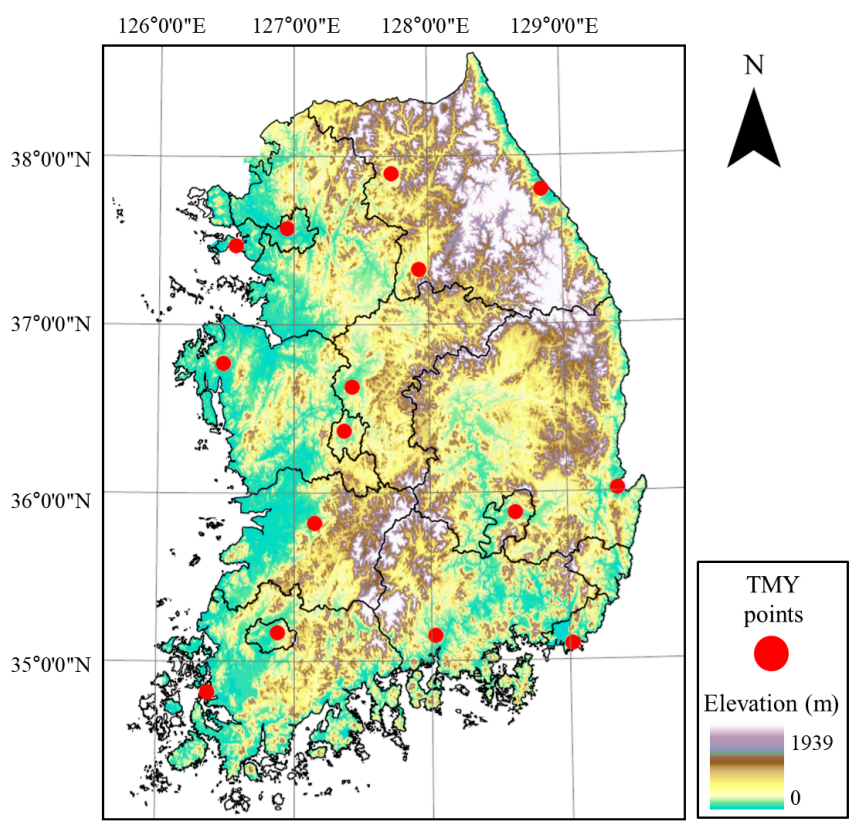

Figure 2. Digital Elevation Model (DEM) and Typical Meteorological Year (TMY) data observation points in Korea.

\section{Methods}

Figure 3 shows the study process used to select suitable reservoirs for installing floating PV from approximately 3400 reservoirs in South Korea and to evaluate the expected effect. This study process can be summarized as follows. In the first step, TMY data were used to predict the daily average solar irradiance, considering the annual irradiance of South Korea. In this process, an interpolation method was applied. However, this solar irradiance map does not take into account the effects of the terrain. In the second step, we performed topographic analysis using the DEM to account for the influence of the shadow caused by the terrain. An average daily irradiance map was created based on topography, taking into account the shadowing ratio and solar irradiance map created in the first step. In the third 
step, reservoirs that do not have sufficient water depth were excluded from the analysis. In the fourth step, the possible power production of the floating PV system of each reservoir was estimated by considering the meteorological data and system design parameters. In the fifth step, the economic feasibility and reduction in GHG emissions by administrative districts were evaluated based on the expected power production.

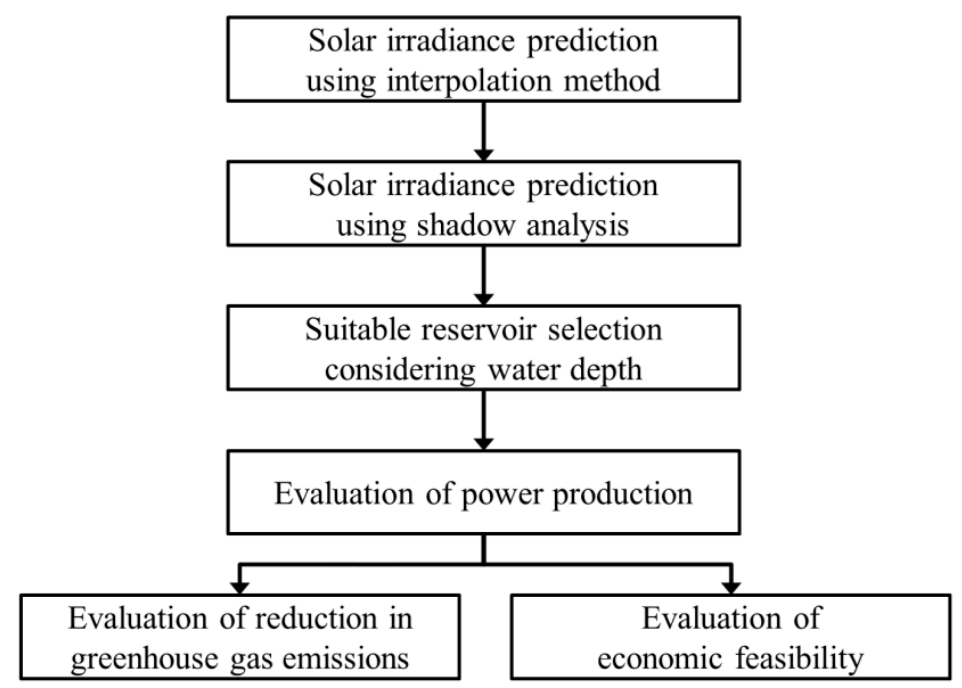

Figure 3. Overall study process to select suitable reservoirs and assess the potential of floating photovoltaic systems in Korea.

\subsection{Point Irradiance Calculation and Interpolation}

The solar irradiance was calculated based on an equal-area-equal-angle sky division grid [17] with the TMY dataset of 16 cities. Beam and diffuse irradiances for each position in the celestial sphere were calculated by summing all the irradiance over the entire year for a time interval. This study refers to this irradiance intensity map of the sky as Sunmap. Figure 4a shows the average of Sunmap for a tilt angle of $20^{\circ}$ from all 16 cities, and Figure $4 \mathrm{~b}$ shows the average of total irradiance as a function of solar panel direction.

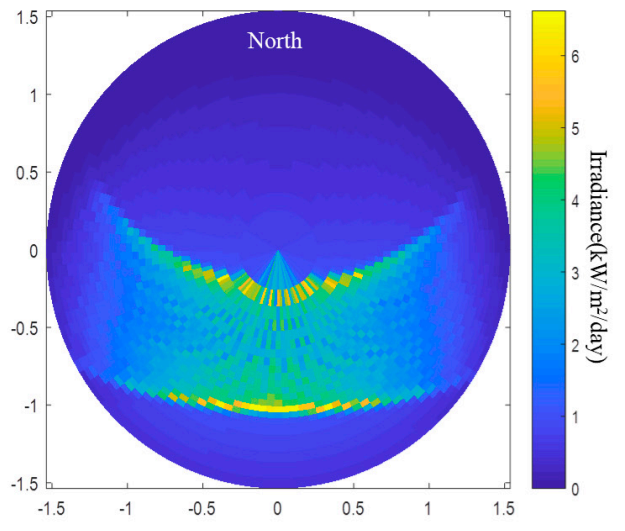

(a)

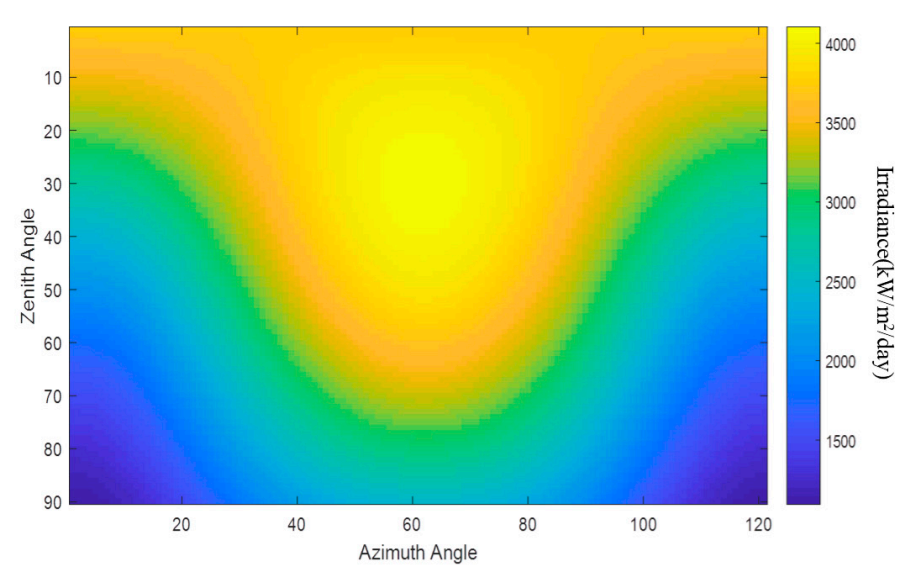

(b)

Figure 4. (a) Mean Sunmap of TMY dataset in Korea with a tilt angle $20^{\circ}$; (b) Mean total irradiance with respect to solar panel direction.

The top is north, and the center point represents the zenith. The sky diffuse model [18] is used when calculating the diffuse irradiance in the sky. The total incident irradiance of the tilted surface is 
the summation of all positive normal intensities from the entire sky. Considering the irradiance of each city in the TMY dataset, it was assessed that the optimal panel direction of Korea is southward, and the optimal tilt angle is about $30^{\circ}$ for most cities. However, many solar panels in the floating PV system have been installed with a tilt angle close to horizontal. National Renewable Energy Laboratory (NREL, Golden, Colorado, USA) research has shown that a tilt angle of $11^{\circ}$ is the typical mounting angle for floating solar systems in Tokushima, Japan [19]. Other installed systems in Italy and Singapore also have a tilt angle close to the horizontal [20]. This preference is derived for reasons such as maximizing power density or structural stability. Therefore, this study sets a tilt angle of $20^{\circ}$, which has a difference in irradiance of less than $1 \%$, compared to a tilt of $30^{\circ}$.

Point irradiance data was interpolated to generate an irradiance map to estimate the irradiance in all areas in Korea. Interpolation is a technique to estimate values between known data. Kriging is a widely used geostatistical interpolation method, which calculates weighting from the correlation of known points. Although it is statistically powerful and is preferred in many cases, a sufficient number of points is necessary to estimate the statistical relationship of each point. Therefore, kriging is not applicable in this study, so the inverse distance weighting (IDW) method was applied. IDW is a deterministic method, which is frequently used in many studies [21]. As shown in Equation (1), the IDW method interpolates unknown values based on distances and values of known points.

$$
I_{p}=\frac{\sum_{i=1}^{n} \frac{I_{i}}{d_{i}^{P}}}{\sum_{i=1}^{n} \frac{1}{d_{i}^{P}}}
$$

where $I_{p}$ is the irradiance of an unknown point, $n$ is number of points, $i$ is an index of a point, $I_{i}$ is irradiance of the known $i$ th point, $d_{i}$ is the distance between the unknown point and the known $i$ th point, and $P$ is power parameter. This method was used to generate a renewable energy resource atlas in Korea [22]. In addition, Evrendilek et al. [23] showed that the accuracies of IDW and co-kriging are similar for Turkey.

\subsection{Solar Irradiance Map based on Shadow Analysis}

As the study area has mountainous terrain, calculating shadowing is an essential process. Whether the sky is covered by terrain or not is determined using the DEM for each position in the Sunmap grid. This sky coverage map is referred to as Viewmap and is used to calculate the shadowed irradiance or sunshine duration. Details of the process are described in Oh et al. [17]. The annual sunshine duration is calculated based on Sunmap and Viewmap.

The annual sunshine duration is calculated considering the effect of shadows, but the difference in irradiance at different times is not considered. For example, even though the sunshine duration in the morning or evening is the same as the sunshine duration at noon, the irradiance in the morning or evening is smaller. To solve this problem, this study used an hourly weight. Figure 5 shows the hourly distribution of irradiance, which is the hourly irradiance divided by the total irradiance, for each city in the TMY dataset. This shows that the hourly distribution for all cities is similar. Therefore, this study assumes that the pattern of hourly distribution of irradiance is the same for every location. Based on this assumption, the sunshine duration for each hour is calibrated as the shadowless ratio by considering the weighting according to the hourly distribution of irradiance. 


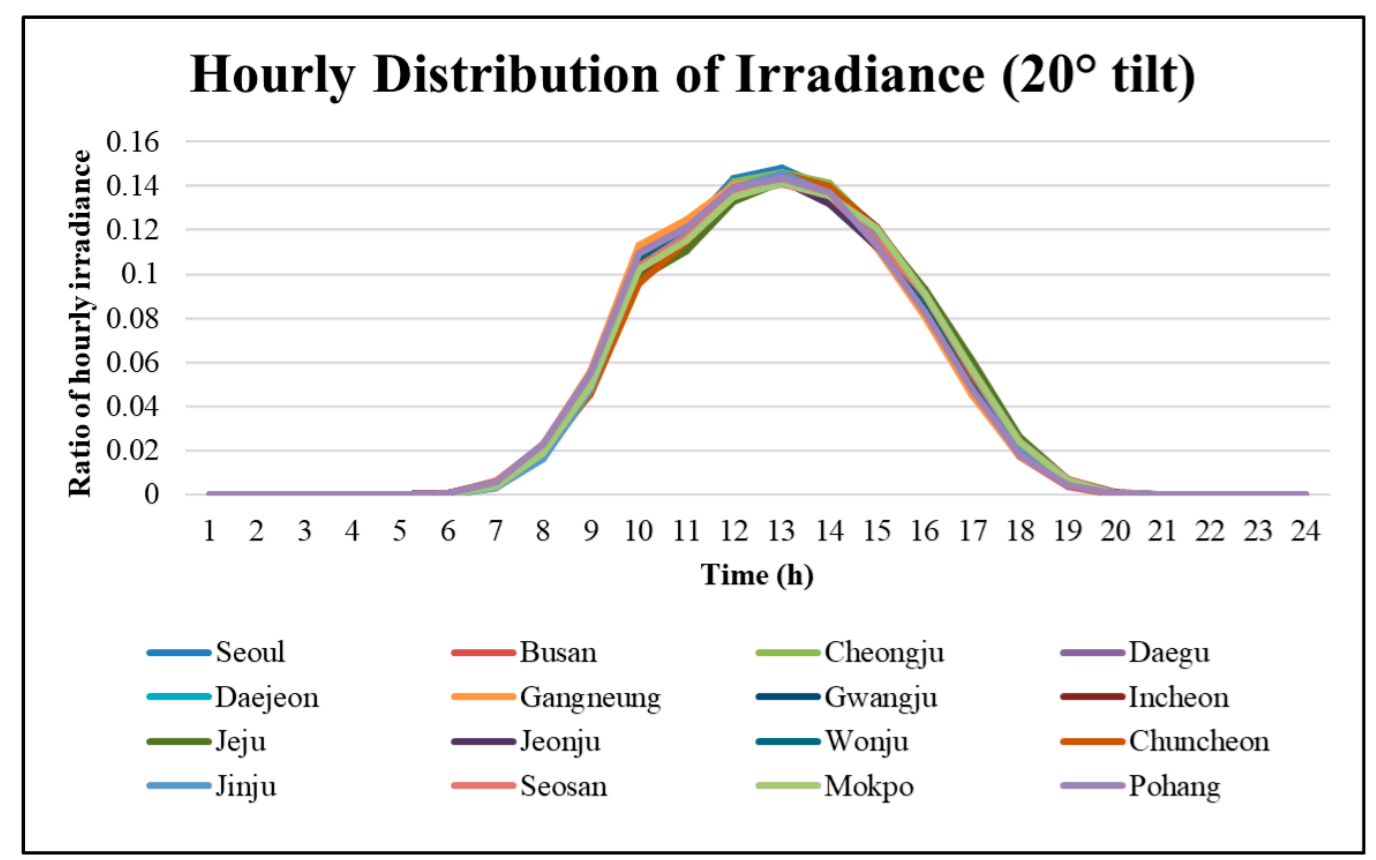

Figure 5. Graph of the ratio of hourly irradiance of each city in TMY dataset.

Equation (2) shows the equation for the hourly weight calculation, and Equation (3) shows the equation for irradiance considering shadows,

$$
\begin{gathered}
W_{h}=\frac{S_{h}}{S_{\operatorname{maxh}}} \times \frac{I_{t h}}{\sum_{i=1}^{24} I_{t i}} \\
I_{s p}=\left(\sum_{h=1}^{24} W_{h}\right) I_{p}
\end{gathered}
$$

where $h$ is the time index $W_{h}$ is the weight at each time $h, I_{t h}$ is annual irradiance of the TMY dataset at time $h, S_{h}$ is sunshine duration at time $h, S_{\operatorname{maxh}}$ is maximum sunshine duration at time $h$, and $I_{s p}$ is irradiance considering shadows of the unknown point. The ratio of sunshine duration and the hourly distribution of irradiance of the TMY dataset is calculated in Equation (2). Mean values for the entire TMY dataset are used in the calculation. The weight at each time is the multiplication of these two ratios. The summation of all hourly weights is used as the total weight, equal to 1 when there are no shadows and equal to 0 when that position is fully shadowed.

The irradiance map assuming shadows (Figure 6c) is generated by the multiplication of the interpolated irradiance map (Figure 6a) and total weight map (Figure 6b). This map can represent both the influence of weather and terrain. The spatial resolution of the map is $90 \mathrm{~m}$, which is equal to that of the DEM. 


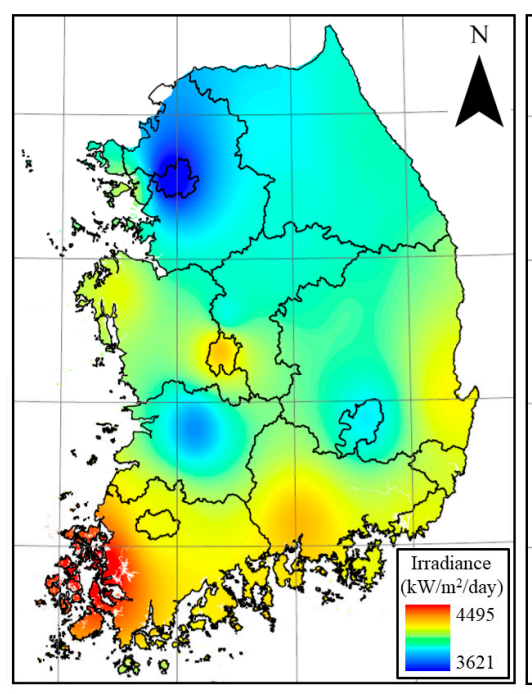

(a)

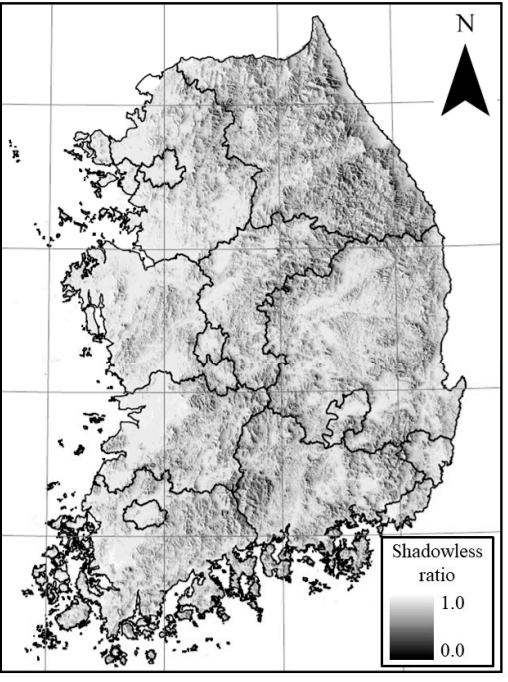

(b)

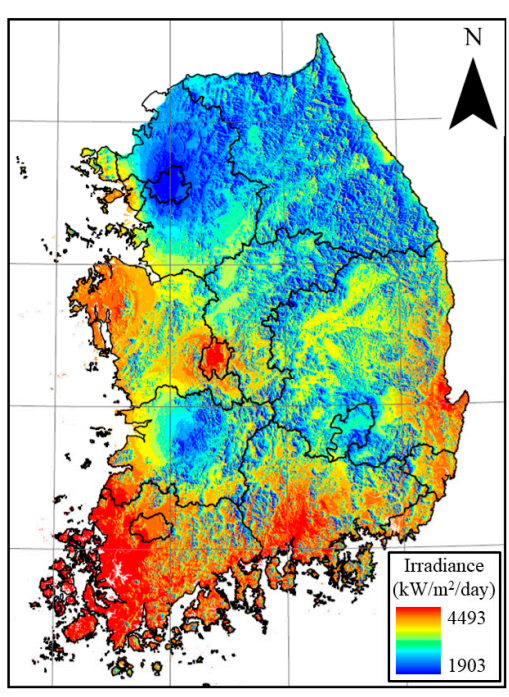

(c)

Figure 6. Irradiance prediction: (a) interpolated irradiance map; (b) shadowless ratio map; (c) irradiance map considering shadow by terrain.

\subsection{Constraint Analysis on Reservoir Depth}

In general, for smooth installation and operation of the floating PV, a reservoir with a water depth greater than $5 \mathrm{~m}$ is recommended, maintaining a water depth of at least $1 \mathrm{~m}$ [24]. Therefore, reservoirs that do not meet these conditions were excluded in this study. In fact, a floating PV of $465 \mathrm{~kW}$ installed in the Geumgwang reservoir in Korea had difficulty in operation because of a summer drought that caused the bottom of the reservoir to be revealed [25]. The KRC provides the daily water level for each reservoir using OpenAPI. The data format is XML, and the API service type is REST type. When the standard code and search period are requested as parameters, the server provides the daily level for that period. Since only one standard code for a particular reservoir can be input in one request, Python-based coding was performed to obtain data for more than 3000 reservoirs. The Requests module from Python was used for OpenAPI requests, and the BeautifulSoup module was used for parsing XML data. Since the water level is provided as an elevation, the water depth was calculated by subtracting the dead water level of each reservoir from the water level. This study constructed a reservoir depth database of 2017 and used it for analysis because for some reservoirs there is no data before 2017.

\subsection{Design and Evaluation of the PV System}

In this study, it is assumed that the solar PV panels are installed in a fixed-tilt array with a $20^{\circ}$ slope facing south. The annual power production of the PV system was calculated using the formula of RETScreen software developed by Natural Resources Canada (NRC, Ottawa, Canada). RETScreen evaluates the power of the PV system via Equation (4),

$$
E_{A}=H_{t} \times S \times \eta_{r} \times \eta_{i n v} \times\left[1-\beta_{p} \times\left(T_{c}-25\right)\right] \times\left(1-\lambda_{p}\right) \times\left(1-\lambda_{c}\right)
$$

where $E_{A}$ is the amount of power $(\mathrm{kWh} / \mathrm{h})$ produced by a PV system, $H_{t}$ is solar irradiation per unit area per unit time $\left(\mathrm{kWh} / \mathrm{m}^{2} / \mathrm{h}\right), S$ is a surface area $\left(\mathrm{m}^{2}\right)$ of the solar array, $\eta_{r}$ is conversion efficiency $(0-1)$ of the solar cell module, $\eta_{i n v}$ is conversion efficiency of the inverter, $\beta_{p}$ is temperature coefficient related to the efficiency of the solar cell module, $T_{c}\left({ }^{\circ} \mathrm{C}\right)$ is average temperature of the solar cell module, $\lambda_{p}$ is loss coefficient of the solar cell module, and $\lambda_{c}$ is loss coefficient of the inverter [26]. Table 1 shows the parameters for the solar panel and inverter used in this study. In this study, the number and surface area of the panels that can be installed are calculated, considering the area of each reservoir, 
the area of one panel, and array spacing. Then, this result is substituted into equation (4), and finally, the power production is estimated.

Table 1. Design parameters for the photovoltaic systems considered in this study.

\begin{tabular}{ccc}
\hline Type & Parameter & Value \\
\hline & Model & SPR-210-BLK \\
Solar cell module & Width $(\mathrm{m})$ & 1.56 \\
& Power capacity $(\mathrm{kW} /$ unit) & 0.80 \\
& Efficiency $(\%)$ & 0.21 \\
& Nominal Operating cell temperature $\left({ }^{\circ} \mathrm{C}\right)$ & 16.9 \\
& Temperature coefficient $\left(\% /{ }^{\circ} \mathrm{C}\right)$ & 46 \\
Lnverter & Losses $(\%)$ & -0.4 \\
& Model & 1 \\
\hline & Efficiency $(\%)$ & SPR-12000f \\
& Capacity $(\mathrm{kW} /$ unit $)$ & 95.5 \\
& Losses $(\%)$ & 12.5 \\
\hline
\end{tabular}

The parameters of solar panel and inverter in this study are the values of the products that are commercially available and are produced on an industrial scale. If more efficient equipment is installed in the reservoirs than Table 1, then the total power production and environmental benefit will increase further. In that case, however, the overall cost will increase, and the economic burden will also increase. Therefore, appropriate selection should be made according to technology level and economic conditions at installation. According to Battaglia et al. [27], current silicon solar cells technology achieved over $25 \%$ of efficiency, and several advanced concepts have been proposed to overcome single-junction solar cells. In addition, silicon hetero-junction solar cell achieved over $26 \%$ of efficiency [28]. Therefore, more efficient equipment is expected to be installed at a lower cost in the future.

\subsection{Economic Assessment and GHG Reduction}

In this study, an economic assessment is performed in terms of the cost of the PV system and the profit from the power production. The cost of a PV system can be separated into the initial installation costs and operating costs. According to the Korea Energy Economics Institute (KEEI, Ulsan, Korea) [29], the installation cost is about $1.43 \mathrm{USD} / \mathrm{W}$, and the annual operating cost is about $10.38 \mathrm{USD} / \mathrm{kW}$. The RPS system was used to estimate the revenue generated by electricity production and sales. The RPS system calculates the electricity sales revenue by summing the system marginal price (SMP) and renewable energy certificates (REC). Here, SMP refers to the revenue from the sale of electricity through the Korea Power Exchange (KPX, Naju, Korea). REC is a tradable, non-tangible energy commodity that represents $1 \mathrm{MWh}$ of electricity generated from an eligible renewable energy resource. Since the prices of SMP and REC are constantly changing, this study used the average value of the amount traded in Korea since 2018. SMP and REC prices are 82.93 USD/MWh and 89.06 USD/MWh, respectively. In addition, in Korea, the power generated by a floating PV is multiplied by a REC weight of 1.5308 .

The net present value (NPV) of the PV system was also calculated by Equation (5).

$$
\mathrm{NPV}=\sum_{t=1}^{N} \frac{E_{t}-C_{t}}{(1+r)^{t}}-C_{0}
$$

where $N$ is the system operating period (20 y in this study), $E_{t}$ is annual electricity sales revenue (USD), $C_{t}$ the annual operating cost (USD), $r$ is the discount rate, and $C_{0}$ is initial cost (USD). A discount rate 
of $5.5 \%$ was applied in this study, according to KEEI [30]. The payback year can be determined by calculating $N$, satisfying the condition that NPV becomes zero in Equation (5).

GHG reduction was also calculated in this study by multiplying the GHG emission reference value (0.4415 $\left.\mathrm{tCO}_{2} / \mathrm{MWh}\right)$ and total amount of power (MWh/year). GHG reduction refers to the amount of GHG generated when the same amount of power produced through renewable energy is generated through the fossil energy system.

\section{Results}

Figure 7 shows the variation in the mean water depth over one year by distinguishing reservoirs for each province. In Gangwon-do, the number of reservoirs is small, but the reservoirs have a deep water depth. On the other hand, Jeollanam-do has the highest number of water reservoirs but the lowest average water depth. Commonly, the water depth falls rapidly from May to July and tends to recover after July. Figure 8 shows the map of the average water depth for each reservoir over the course of a year. There are a considerable number of reservoirs that are not suitable for floating PV installations, in which the average water depth is less than $5 \mathrm{~m}$. There are many reservoirs in Jeolla-do and Gyeongsang-do, but many reservoirs are low in water depth.

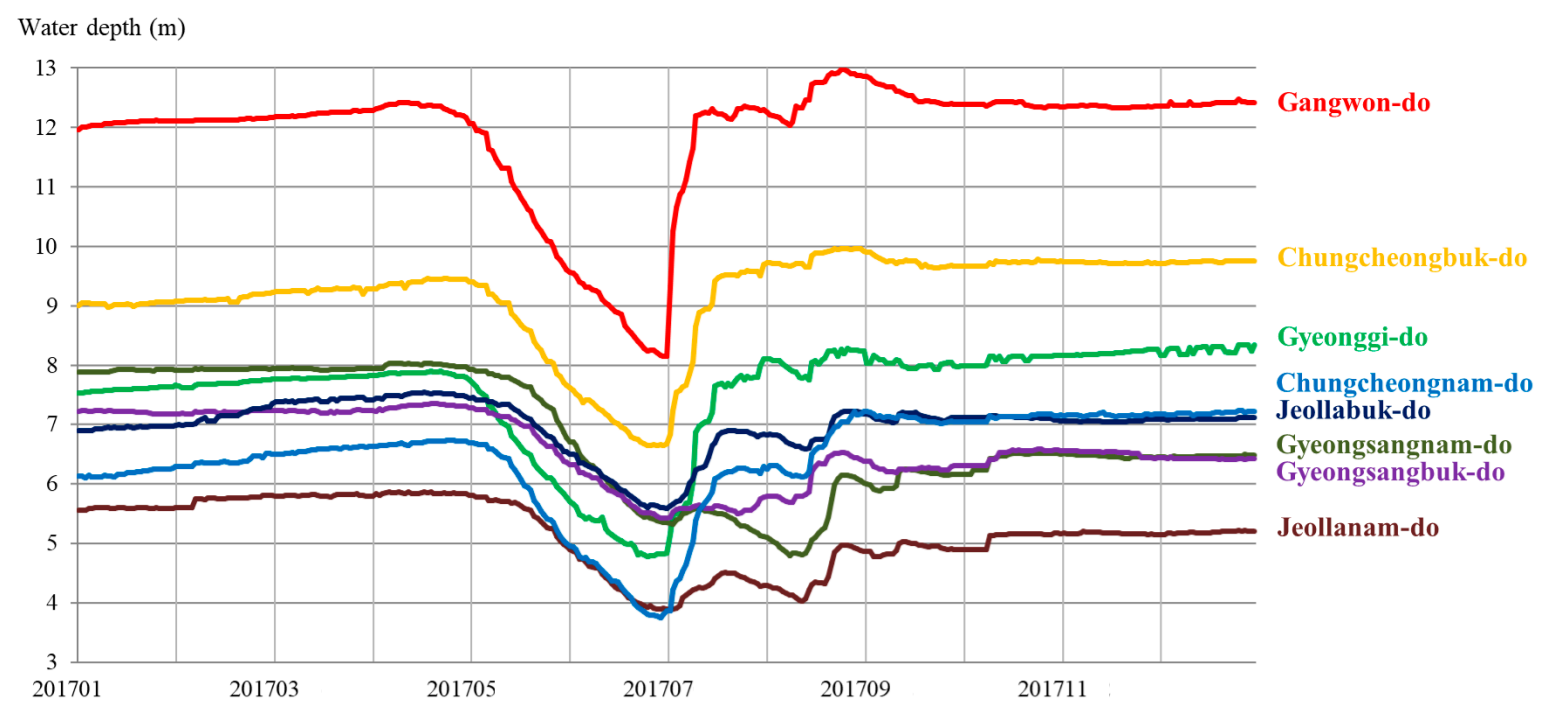

Figure 7. The variation of mean water depth over one year for reservoirs of each province.

The floating PV capacity and power production of each reservoir was calculated considering the solar irradiance, characteristics of the panel, and installation area of the panel. In this study, an additional $11 \%$ efficiency was considered for the use of the floating PV. The results for all reservoirs are shown in Table 2, based on the ratio of the installation area for the reservoirs satisfying the water depth requirements assumed above. Only reservoirs with a floating PV capacity of $100 \mathrm{~kW}$ or greater were considered. Generally, it is common to install floating PV panels in 10\% of the reservoir area. In this case, 1134 reservoirs satisfy the condition, and the total installed capacity of the panels is about 2103 MW, with an annual power production of 2932 GWh. In recent years, a floating PV has been installed for a high percentage of the reservoir area in several cases [31]. If a floating PV is installed over the entire area of the reservoir under extreme assumptions, the total installed capacity of the panel is estimated to be $21,093 \mathrm{MW}$, and the annual power production is estimated to be 29,409 GWh. 


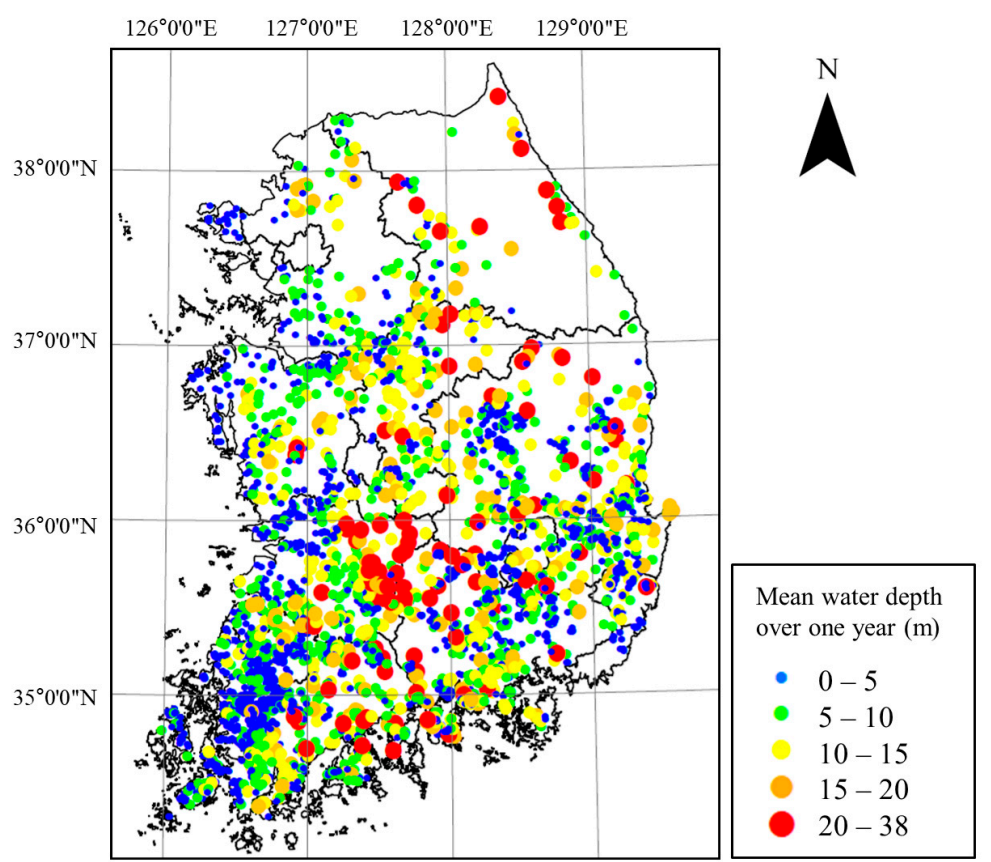

Figure 8. The map of the average water depth for each reservoir over a year.

Figure $9 \mathrm{a}$ is a map showing the annual electricity usage for the administrative units of Korea in 2017. Metropolitan cities or industrial cities such as Seoul, Ulsan, Incheon, and Busan show relatively high electricity usage, and their annual electricity consumption is about 46,493 GWh, 32,095 GWh, 23,876 GWh, and 20,467 GWh, respectively. Figure 9b shows what percentage of electricity usage can be satisfied when a floating PV is installed in each administrative unit. It is assumed that solar panels are installed in $10 \%$ of the reservoir area. It is estimated that Jeolla-do, which has a relatively low power consumption and is favorable for floating PV installation, can supply a large portion of the electric power demand in comparison with other provinces. For example, it is estimated that about $41 \%$ of the power demand of Imsil in Jeollabuk-do and $16 \%$ of the power demand of Gangjin in Jeollanam-do can be covered by floating PV power generation.

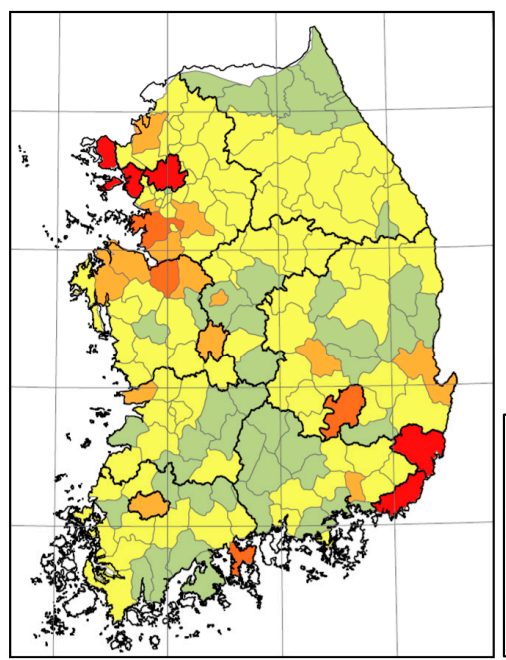

(a)

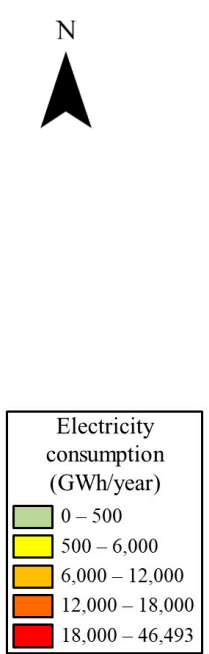

$18,000-46,493$

Figure 9. (a) Map of the annual electricity usage for the administrative units and (b) map of the demand-to-supply ratio for electricity usage.

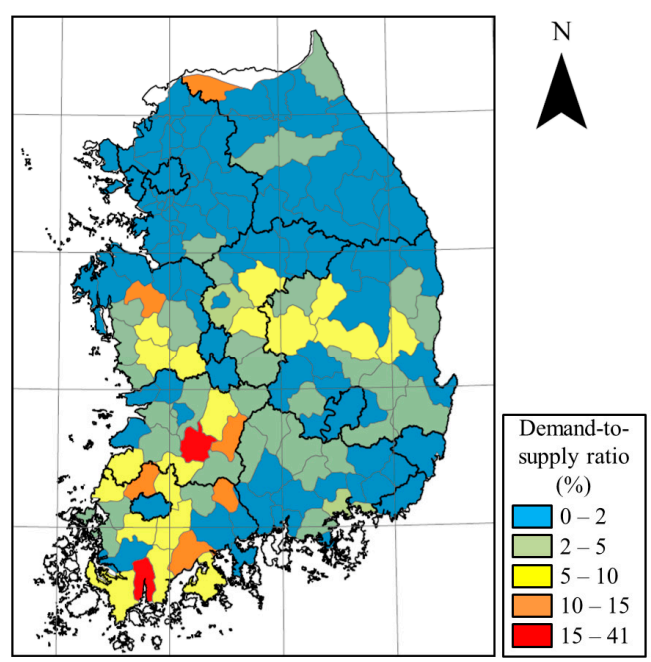

(b) 
Table 3 shows the overall results of reservoir condition, installed floating PV capacity, annual power production, and GHG reduction of each province. It can be seen that Jeollanamdo, Gyeongsangbuk-do, and Chungcheongnam-do, which have high solar irradiance and a large number of reservoirs, have high power production and high GHG reduction. If a floating PV is installed in 10\% of the area for all reservoirs, the expected annual power production is $2932 \mathrm{GWh}$, and the annual GHG reduction amount is approximately 1,294,450 ton.

Assuming that a floating PV is installed in $10 \%$ of the reservoir area, the analysis results of the top 10 reservoirs (Figure 10) with the highest power production are shown in Table 4. In this case, a larger reservoir area corresponds to more power generation. Therefore, the top 10 reservoirs with high economic efficiency were also analyzed for an installed 100-kW floating PV (476 units of PV panel with 0.21-kW capacity). For a floating PV installed in proportion to the area of the reservoir, the analysis shows that maximum power production corresponds to a PV installed in Yedang reservoir, located in Chungcheongnam-do. In this case, reservoirs suitable for floating PV installations are distributed nationwide. On the other hand, in terms of economic efficiency, reservoirs of Jeollanam-do with high solar irradiance were found to be advantageous.

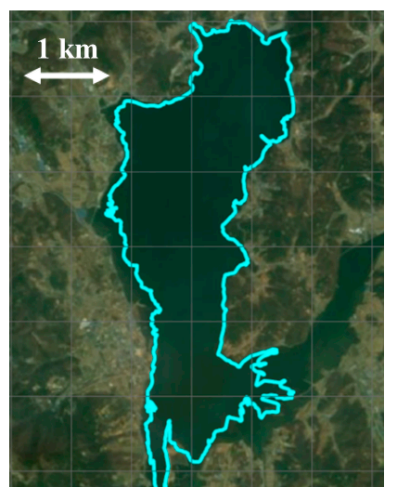

(a)

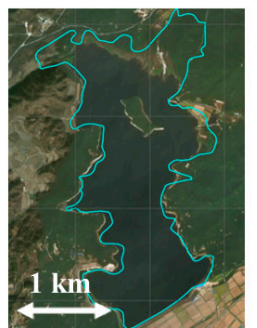

(e)

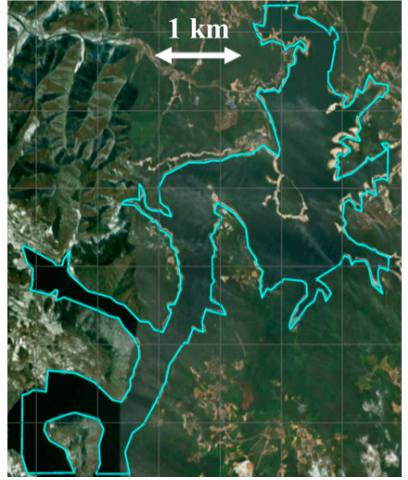

(b)

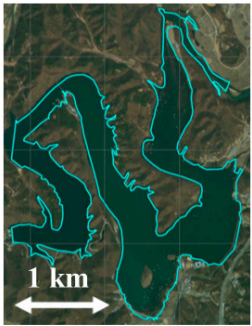

(f)

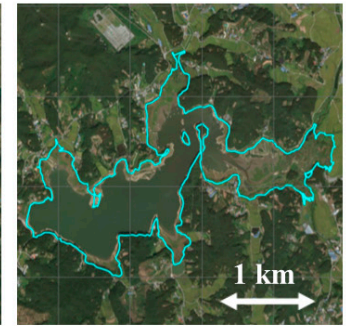

(g)

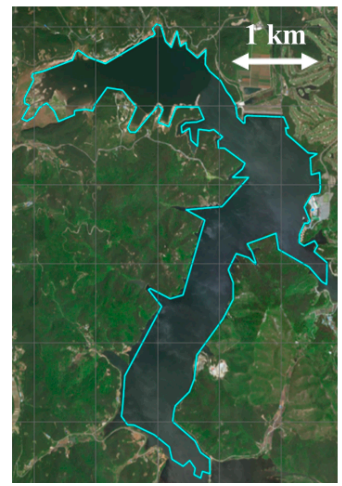

(c)

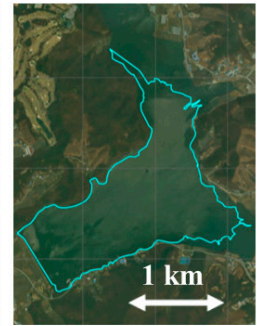

(h)

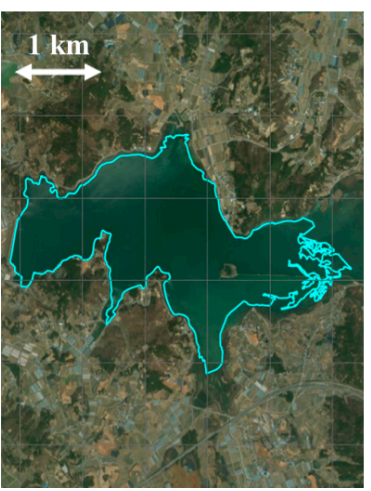

(d)

Figure 10. Boundary data and satellite images of top 10 reservoirs with the highest power production: (a) Yedang; (b) Seomjin; (c) Najuho; (d) Topjeong; (e) Togyo; (f) Miho; (g) Gosam; (h)Bulgop; (i) Yidong; (j) Deokdong. 
Table 2. The results of floating photovoltaic system installations according to the ratio of the installation area for all reservoirs satisfying the water depth requirements.

\begin{tabular}{ccccccccccc}
\hline Installation area to reservoir area ratio (\%) & 10 & 20 & 30 & 40 & 50 & 60 & 70 & 80 & 100 \\
\hline Number of reservoirs satisfying 100 $\mathbf{~ k W}$ & 1134 & 1201 & 1218 & 1225 & 1230 & 1234 & 1236 & 1236 & 1236 & 1236 \\
Maximum capacity (MW) & 75.85 & 151.70 & 227.55 & 303.40 & 379.25 & 455.10 & 530.95 & 606.80 & 682.65 & 758.50 \\
Total capacity (MW) & 2102.89 & 4216.33 & 6326.63 & 8436.33 & $10,545.97$ & $12,655.63$ & $14,765.12$ & $16,874.42$ & $18,983.73$ & $21,093.03$ \\
Total power production (GWh/year) & 2931.94 & 5878.65 & 8820.95 & $11,762.40$ & $14,703.79$ & $17,645.20$ & $20,586.38$ & $23,527.30$ & $26,468.21$ & $29,409.12$ \\
\hline
\end{tabular}

Table 3. The results of reservoir condition, installed floating photovoltaic (PV) capacity, annual power production, and greenhouse gas (GHG) reduction of each province.

\begin{tabular}{|c|c|c|c|c|c|c|c|c|c|c|c|}
\hline & $\begin{array}{l}\text { Number of } \\
\text { Reservoirs }\end{array}$ & $\begin{array}{c}\text { Mean } \\
\text { Water } \\
\text { Depth }(\mathrm{m})\end{array}$ & $\begin{array}{c}\text { Mean } \\
\text { Reservoir } \\
\text { Area }\left(\mathbf{k m}^{2}\right)\end{array}$ & $\begin{array}{c}\text { Mean } \\
\text { Irradiance } \\
\text { (kW/m }^{2} \\
\text { /day) }\end{array}$ & $\begin{array}{l}\text { Mean PV } \\
\text { Capacity } \\
\text { (MW) }\end{array}$ & $\begin{array}{c}\text { Maximum } \\
\text { PV } \\
\text { Capacity } \\
\text { (MW) }\end{array}$ & $\begin{array}{c}\text { Total PV } \\
\text { Capacity } \\
\text { (MW) }\end{array}$ & $\begin{array}{c}\text { Mean } \\
\text { Power } \\
\text { Production } \\
\text { (GWh/year) }\end{array}$ & $\begin{array}{l}\text { Maximum } \\
\text { Power } \\
\text { Production } \\
\text { (GWh/year) }\end{array}$ & $\begin{array}{l}\text { Total Power } \\
\text { Production } \\
\text { (GWh/year) }\end{array}$ & $\begin{array}{c}\text { Total GHG } \\
\text { Reduction } \\
(\mathbf{1 0 0 0} \\
\text { tCO }\end{array}$ \\
\hline Gangwon-do & 48 & 12.09 & 0.50 & 3714.40 & 2.43 & 30.28 & 116.81 & 3.28 & 41.21 & 157.36 & 69.47 \\
\hline Gyeonggi-do & 50 & 9.78 & 0.64 & 3704.45 & 3.61 & 24.60 & 180.60 & 4.88 & 34.20 & 244.19 & 107.81 \\
\hline Gyeongsangnam-do & 167 & 12.23 & 0.22 & 3864.00 & 0.81 & 6.22 & 135.27 & 1.11 & 8.73 & 184.85 & 81.61 \\
\hline Gyeongsangbuk-do & 227 & 11.26 & 0.38 & 3814.96 & 1.75 & 20.48 & 397.25 & 2.45 & 29.07 & 556.32 & 245.62 \\
\hline Jeollanam-do & 285 & 9.96 & 0.32 & 3987.81 & 1.50 & 54.94 & 427.50 & 2.17 & 80.51 & 617.29 & 272.53 \\
\hline Jeollabuk-do & 149 & 12.37 & 0.38 & 3798.40 & 1.95 & 75.25 & 290.11 & 2.67 & 102.39 & 397.32 & 175.42 \\
\hline Chungcheongnam-do & 98 & 9.78 & 0.61 & 3877.83 & 3.65 & 75.85 & 357.75 & 5.16 & 107.58 & 505.29 & 223.09 \\
\hline Chungcheongbuk-do & 110 & 12.43 & 0.40 & 3781.62 & 1.79 & 26.56 & 197.18 & 2.45 & 36.71 & 269.32 & 118.90 \\
\hline Sum & 1134 & & & & & & 2068.53 & & & 2931.94 & 1294.45 \\
\hline
\end{tabular}


Table 4. The analysis results of the top 10 reservoirs with the highest power production and with the highest efficiency.

\begin{tabular}{|c|c|c|c|c|c|c|c|c|c|c|}
\hline & Rank & Reservoir Name & Province & City & $\begin{array}{l}\text { Reservoir } \\
\text { Area }\left(\mathbf{k m}^{2}\right)\end{array}$ & $\begin{array}{c}\text { Capacity } \\
\text { (MW) }\end{array}$ & $\begin{array}{c}\text { Power } \\
\text { Production } \\
\text { (GWh/year) }\end{array}$ & $\begin{array}{c}\text { GHG } \\
\text { Reduction } \\
\text { (ton) }\end{array}$ & $\begin{array}{c}\text { NPV } \\
(10,000 \\
\text { USD) }\end{array}$ & $\begin{array}{r}\text { Pay } \\
\text { Back } \\
\text { (year) }\end{array}$ \\
\hline \multirow{10}{*}{$\begin{array}{l}\text { Floating PV } \\
\text { installed in } \\
\text { proportion to the } \\
\text { area of the } \\
\text { reservoir } \\
\text { (High power } \\
\text { production) }\end{array}$} & 1 & Yedang & Chungcheongnam-do & Yesan & 8.83 & 75.85 & 107.58 & $47,494.86$ & $17,513.99$ & 4.42 \\
\hline & 2 & Seomjin & Jeollabuk-do & Imsil & 10.11 & 75.25 & 102.39 & $45,205.39$ & $16,191.54$ & 4.70 \\
\hline & 3 & Najuho & Jeollanam-do & Naju & 7.19 & 54.94 & 80.51 & $35,544.71$ & $13,392.70$ & 4.21 \\
\hline & 4 & Topjeong & Chungcheongnam-do & Nonsan & 5.82 & 47.20 & 67.77 & $29,921.57$ & $11,125.65$ & 4.34 \\
\hline & 5 & Togyo & Gangwon-do & Cheorwon & 3.92 & 30.28 & 41.21 & $18,195.17$ & 6518.30 & 4.69 \\
\hline & 6 & Miho & Chungcheongbuk-do & Jincheon & 4.42 & 26.56 & 36.71 & $16,206.52$ & 5869.99 & 4.59 \\
\hline & 7 & Gosam & Gyeonggi-do & Anseong & 3.56 & 24.60 & 34.20 & $15,101.31$ & 5493.85 & 4.55 \\
\hline & 8 & Bulgop & Jeollanam-do & Yeonggwang & 3.20 & 21.44 & 31.70 & $13,996.68$ & 5304.63 & 4.15 \\
\hline & 9 & Yidong & Gyeonggi-do & Yongin & 2.87 & 22.00 & 30.31 & $13,382.42$ & 4836.23 & 4.61 \\
\hline & 10 & Deokdong & Gyeongsangbuk-do & Gyeongju & 3.11 & 20.48 & 29.08 & $12,836.71$ & 4736.96 & 4.41 \\
\hline \multirow{10}{*}{$\begin{array}{l}\text { Floating PV with } \\
100 \mathrm{~kW} \text { capacity } \\
\text { (High efficiency) }\end{array}$} & 1 & Naesan & Jeollanam-do & Haenam & 0.11 & 0.10 & 0.16 & 69.08 & 27.08 & 3.82 \\
\hline & 2 & Jangsan & Jeollanam-do & Shinan & 0.14 & 0.10 & 0.16 & 69.04 & 27.06 & 3.82 \\
\hline & 3 & Gopyeong & Jeollanam-do & Haenam & 0.08 & 0.10 & 0.16 & 68.86 & 26.95 & 3.84 \\
\hline & 4 & Cheongsu & Jeollanam-do & Muan & 0.15 & 0.10 & 0.16 & 68.54 & 26.75 & 3.86 \\
\hline & 5 & Illo & Jeollanam-do & Muan & 0.75 & 0.10 & 0.15 & 68.39 & 26.66 & 3.88 \\
\hline & 6 & Gwangdae & Jeollanam-do & Shinan & 0.41 & 0.10 & 0.15 & 68.21 & 26.55 & 3.89 \\
\hline & 7 & Sindeok & Jeollanam-do & Yeongam & 0.13 & 0.10 & 0.15 & 68.20 & 26.54 & 3.89 \\
\hline & 8 & Dopyeong & Jeollanam-do & Jindo & 0.11 & 0.10 & 0.15 & 68.09 & 26.48 & 3.90 \\
\hline & 9 & Sungdong & Jeollanam-do & Muan & 0.17 & 0.10 & 0.15 & 68.02 & 26.43 & 3.91 \\
\hline & 10 & Sungyang & Jeollanam-do & Yeongam & 0.40 & 0.10 & 0.15 & 67.77 & 26.28 & 3.93 \\
\hline
\end{tabular}




\section{Conclusions}

In this study, we analyzed the water level data of 3401 reservoirs in Korea using OpenAPI and extracted reservoirs suitable for floating PV installation. In this analysis, the conditions of an average reservoir water depth greater than $5 \mathrm{~m}$ and minimum water depth greater than $1 \mathrm{~m}$ were considered. GIS spatial analysis was applied to the TMY dataset to predict the national distribution of solar irradiance for shadow conditions. Assuming an expected power production of $10 \%$ of the area of all reservoirs satisfying the conditions, the annual power production was estimated to be 2932 GWh, and the annual GHG reduction amount was estimated to be 1,294,450 ton. In particular, Jeollanam-do has many reservoirs, including many suitable for floating PV installation because of high solar irradiance. The results of this study can be used to estimate priorities and potentiality prior to actual floating PV installation and detailed analysis. This study did not take degradation into consideration because it is aimed at estimating priorities through relative comparisons. However, as floating PV is installed in the water, it is necessary to study the efficiency change and degradation related to the moisture in actual installation.

The results of this study are very useful for preliminary evaluation at the national level, but improvement is needed in the following points. First, there may be a limit to the prediction accuracy in that only 16 data points are used to predict the solar irradiance. If the irradiance is measured at many more points, accurate irradiance prediction can be made. However, because of budget limitations, it is necessary to continuously increase the number of solar irradiance observation points at the government level. It is also possible to improve the accuracy of solar irradiance prediction through complex analysis with satellite image data. Next, the water level data used in this study is not well managed by the government, and some data are missing or include errors. In this study, we manually identified and corrected these errors. To reflect water level data in real time during the operation of the floating PV in the future, more thorough management of water level data is needed. In addition, this study was carried out to evaluate reservoirs suitable for floating PV installation and to evaluate their overall potential. However, to actually install floating PV in individual reservoirs, a more accurate analysis of the area's solar irradiance, wind speed, accessibility, detailed topography, and other conditions needs to be implemented. Finally, since SMP and REC prices are constantly changing, it is necessary to periodically consider the economic feasibility. The results of this study have important implications in Korea for large-scale floating PV installation in the future. For the successful application of floating PV, a rigorous feasibility assessment and planning for the redistribution of profit is most important, to minimize environmental damage and repudiation from the local residents.

Author Contributions: H.-D.P. conceived and designed the analysis. S.-M.K. and M.O. performed the analysis. S.-M.K. and M.O. developed the code and analyzed the data. H.-D.P. contributed reagents/materials/analysis tools. S.-M.K. wrote the paper.

Funding: This research was funded by the National Research Foundation of Korea (NRF) (No. NRF-2017R1A2B4007623).

Acknowledgments: This research was supported by the Brain Korea 21 Project.

Conflicts of Interest: The authors declare no conflict of interest.

\section{References}

1. The International Renewable Energy Agency (IRENA). Renewable Capacity Statistics 2018; IRENA: Abu Dhabi, United Arab Emirates, 2018.

2. Choi, Y.K. A Study on Power Generation Analysis of Floating PV System Considering Environmental Impact. Int. J. Softw. Eng. Appl. 2014, 8, 75-84. [CrossRef]

3. Sahu, A.; Yadav, N.; Sudhakar, K. Floating photovoltaic power plant: A review. Renew. Sust. Energ. Rev. 2016, 66, 815-824. [CrossRef] 
4. Galdino, M.; de Almeida Olivieri, M.M. Some Remarks about the Deployment of Floating PV Systems in Brazil. J. Elec. Eng. 2017, 5, 10-19. [CrossRef]

5. The World Bank. Where Sun Meets Water: Floating Solar Market Report; The World Bank: Washington, DC, USA, 2018.

6. Minamino, S. Floating Solar Plnats: Niche Rising to the Surface? Available online: https:/ /www.solarplaza. $\mathrm{com} /$ channels/top-10s/11634/floating-solar-plants-niche-rising-surface/ (accessed on 28 December 2018).

7. Osborne, M. China Completes Largest Floating Solar Power Plant. Available online: https://www.pv-tech. org/news / china-completes-largest-floating-solar-power-plant (accessed on 28 December 2018).

8. Lee, Y.G.; Joo, H.J.; Yoon, S.J. Design and installation of floating type photovoltaic energy generation system using FRP members. Sol. Energy 2014, 108, 13-27. [CrossRef]

9. Kim, S.H.; Yoon, S.J.; Choi, W. Design and Construction of 1 MW Class Floating PV Generation Structural System Using FRP Members. Energies 2017, 10, 1142. [CrossRef]

10. Choi, Y.K.; Kim, I.S.; Hong, S.T.; Lee, H.H. A Study on Development of Azimuth Angle Tracking Algorithm for Tracking-type Floating Photovoltaic System. Adv. Sci. Technol. Lett. 2014, 51, 197-202. [CrossRef]

11. Choi, Y.K.; Lee, N.H.; Lee, A.K.; Kim, K.J. A Study on Major Design Elements of Tracking-Type Floating Photovoltaic Systems. Int. J. Smart Grid Clean Energy 2014, 3, 70-74. [CrossRef]

12. Lee, A.K.; Shin, G.W.; Hong, S.T.; Choi, Y.K. A Study on Development of ICT Convergence Technology for Tracking-Type Floating Photovoltaic Systems. Int. J. Smart Grid Clean Energy 2014, 3, 80-87. [CrossRef]

13. Song, J.; Choi, Y.; Yoon, S.H. Analysis of Photovoltaic Potential at Abandoned Mine Promotion Districts in Korea. Geosyst. Eng. 2015, 18, 168-172. [CrossRef]

14. Song, J.; Choi, Y. Analysis of the Potential for Use of Floating Photovoltaic Systems on Mine Pit Lakes: Case Study at the Ssangyong Open-Pit Limestone Mine in Korea. Energies 2016, 9, 102. [CrossRef]

15. Lee, K.R.; Lee, W.H. Floating Photovoltaic Plant Location Analysis using GIS. J. Korean Soc. Geospat. Inf. Syst. 2016, 24, 51-59. [CrossRef]

16. Lee, S.H.; Lee, N.H.; Choi, H.C.; Kim, J.O. Study on Analysis of Suitable Site for Development of Floating Photovoltaic System. J. Korean Inst. Illum. Electr. Install. Eng. 2012, 26, 30-38.

17. Oh, M.; Park, H.D. A new algorithm using a pyramid dataset for calculating shadowing in solar potential mapping. Renew. Energy 2018, 126, 465-474. [CrossRef]

18. Perez, R.; Seals, R.; Michalsky, J. All-Weather Model for Sky Luminance Distribution-Preliminary Configuration and Validation. Sol. Energy 1993, 50, 235-245. [CrossRef]

19. NREL. STAT FAQs Part 1: Floating Solar. Available online: https:/ /www.nrel.gov/state-local-tribal/blog/ posts/stat-faqs-part1-floating-solar.html (accessed on 28 December 2018).

20. Patil, S.S.; Wagh, M.M.; Shinde, N.N. A Review on Floating Solar Photovoltaic Power Plants. Int. J. Sci. Eng. Res. 2017, 8, 789-794.

21. Palmer, D.; Cole, I.; Betts, T.; Gottschalg, R. Interpolating and Estimating Horizontal Diffuse Solar Irradiation to Provide UK-Wide Coverage: Selection of the Best Performing Models. Energies 2017, 10, 181. [CrossRef]

22. Kang, Y.H. KOREA Renewable Energy Resource Atlas; Korea Institute of Energy Research: Daejeon, Korea, 2015.

23. Evrendilek, F.; Ertekin, C. Assessing solar radiation models using multiple variables over Turkey. Clim. Dynam. 2008, 31, 131-149. [CrossRef]

24. LSIS. Floating Photovoltaic System; LS Industrial Systems: Anyang, Korea, 2016.

25. Kim, G.H. Water Solar Power Plant That Sits Down on the Ground Due to Drought. Available online: https:/ / www.yna.co.kr/view/AKR20170626109700061 (accessed on 28 December 2018).

26. RETScreen International Clean Energy Decision Support Centre. Clean Energy Project Analysis, RETScreen Engineering E Cases Textbook; CANMET Energy Technology Centre: Montreal, QC, Canada, 2005.

27. Battaglia, C.; Cuevas, A.; De Wolf, S. High-efficiency crystalline silicon solar cells: Status and perspectives. Energy Environ. Sci. 2016, 9, 1552-1576. [CrossRef]

28. Yoshikawa, K.; Kawasaki, H.; Yoshida, W.; Irie, T.; Konishi, K.; Nakano, K.; Uto, T.; Adachi, D.; Kanematsu, M.; Uzu, H.; et al. Silicon heterojunction solar cell with interdigitated back contacts for a photoconversion efficiency over 26\%. Nat. Energy 2017, 2, 17032. [CrossRef] 
29. Lee, C.Y. Equalization Cost through Solar Cost Analysis International Comparative Analysis; Korea Energy Economics Institute: Ulsan, Korea, 2017.

30. MOTIE. Guidelines for Management and Operation of New and Renewable Energy Supply Mandatory System and Fuel Mixture Mandatory System; Ministry of Trade, Industry and Energy: Sejong, Korea, 2018.

31. Europe's Largest Floating Solar Farm to Open. Available online: https://www.bbc.com/news/uk-englandlondon-35705345 (accessed on 28 December 2018). 